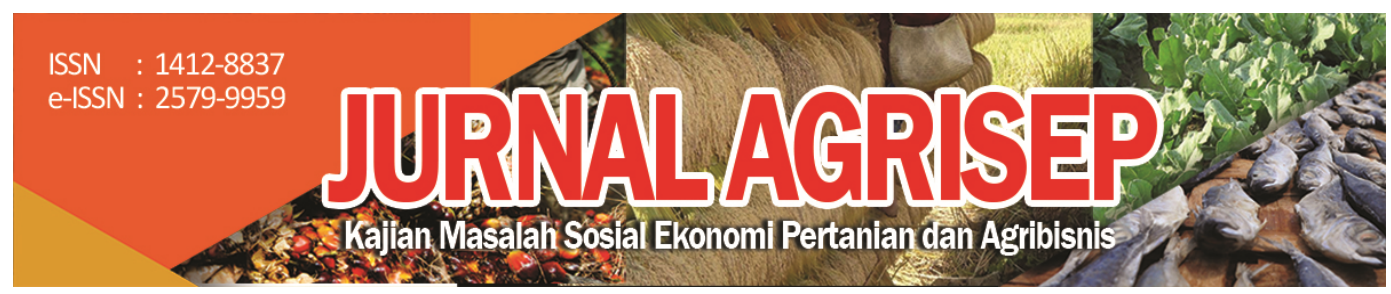

DOI: 10.31186/jagrisep.19.1.219-228

\title{
ANALISIS PERSEPSI PETERNAK AYAM PEDAGING (BROILER) TENTANG KEMITRAAN DI KECAMATAN PONDOK KUBANG KABUPATEN BENGKULU TENGAH
}

\section{PERCEPTION PLASMA BREEDERS ABOUT A PARTNERSHIP IN THE BROILERS CHICKEN IN PONDOK KUBANG SUBDISTRICT BENGKULU TENGAH REGENCY}

\author{
Rahmi Yuristia ${ }^{1}{ }^{凶}$, Bambang Sumantri ${ }^{2)}$ \\ 1),2)Program Studi Agribisnis, Fakultas Pertanian, Universitas Bengkulu \\ Email: rahmiyuristia@unib.ac.id
}

\begin{abstract}
This study aims to analyze farmers' perceptions of partnerships in the Pondok Kubang District. This research was conducted in Bengkulu Tengah Regency, for 5 months from June to October 2019. This type of research is survey research. In this study two types of data are used, namely, primary data obtained from respondents directly and secondary data, obtained from government agencies and related institutions. Measurement of farmers' perceptions and behavior is carried out using a Likert scale or assessment score. Based on the results of the study it was found that farmers 'perceptions of partnerships that have been established are classified as good, this can be seen from the acquisition scores obtained that farmers' perceptions about conformity of opinion with the core company are 75\% of farmers answered Fairly Good with an Average Score of 9.75; farmers' perceptions of the socio-economic benefits of the partnership that have taken place are $75 \%$ of farmers answering Fairly Good with an Average Score of 10.50, and farmers' perceptions of information disclosure between partner farmers and core companies in the partnership are 100\% of breeders answered Good with an average score of 12.25 .
\end{abstract}

Keywords: Perception, Partnerships and plasma breeders 


\begin{abstract}
ABSTRAK
Penelitian ini bertujuan untuk menganalisa persepsi peternak terhadap kemitraan di Kecamatan Pondok Kubang. Penelitian ini dilaksanakan di Kabupaten Bengkulu Tengah, selama 5 bulan dari bulan juni sampai Oktober 2019.

Jenis penelitian ini adalah penelitiaan survey . Pada penelitian ini digunakan dua jenis data yaitu data primer yang diperoleh dari responden secara langsung dan data sekunder, yang diperoleh dari instansi pemerintah dan lembaga terkait. Pengukuran Persepsi dan perilaku peternak dilaksanakan menggunakan skala Likert atau skor penilaian. Berdasarkan hasil penelitian didapatkan bahwa persepsi peternak terhadap kemitraan yang telah terjalin tergolong baik, hal ini terlihat dari skor perolehan yang didapat yaitu persepsi peternak tentang kesesuaian pendapat dengan perusahaan inti adalah 75\% peternak menjawab Cukup Baik dengan Skor Rata-rata 9,75; persepsi peternak di terhadap manfaat social ekonomi dari kemitraan yang telah berlangsung adalah 75\% peternak menjawab Cukup Baik dengan Skor Rata-rata 10,50; dan persepsi peternak terhadap keterbukaan informasi antara peternak mitra dengan perusahaan inti dalam kemitraan adalah 100\% peternak menjawab Baik dengan skor rata-rata 12,25.
\end{abstract}

Kata Kunci : Persepsi, Perilaku Agribisnis, Kemitraan dan peternakan

\title{
PENDAHULUAN
}

Komoditas unggas mempunyai prospek pasar yang sangat baik karena didukung oleh karakteristik produk unggas yang dapat diterima oleh masyarakat Indonesia yang sebagian besar muslim, harga relatif murah dengan akses yang mudah. Hal tersebut menjadikan ia sebagai pilihan penting untuk penyediaan protein hewani nasional. Prospek yang demikian harus dimanfaatkan untuk mendorong pemberdayaan ekonomi peternak di perdesaan melalui pemanfaatan sumberdaya secara lebih optimal.

Komoditas unggas mempunyai prospek pasar yang sangat baik karena didukung oleh karakteristik produk unggas yang dapat diterima oleh masyarakat Indonesia yang sebagian besar muslim, harga relatif murah dengan akses yang mudah. Hal tersebut menjadikan ia sebagai pilihan penting untuk penyediaan protein hewani nasional. Prospek yang demikian harus dimanfaatkan untuk mendorong pemberdayaan ekonomi peternak di perdesaan melalui pemanfaatan sumberdaya secara lebih optimal.

Seiring dengan kemajuan teknologi dan aspek pembangunan lainnya, pemeliharaan ayam ras mengalami perkembangan yang sedemikian pesatnya sehingga sudah menjelma menjadi Industri peternakan. Pemeliharaan ayam ras tidak lagi dilakukan secara tradisional oleh peternak bermodal kecil , tetapi berbagai perusahaan besar juga terlibat dalam bisnis usaha peternakan ayam ras seperti perusahaan suplayer bibit DOC, perusahaan obat - obatan dan 220 | Rahmi Yuristia, Bambang Sumantri; Analisis Persepsi Peternak... 
vaksin hingga perusahaan pakan ternak melalui pola kemitraan antara perusahaan besar dan peternak kecil.

Landasan peraturan mengenai kemitraan di Indonesia diatur oleh Peraturan Pemerintah No. 44 tahun 1997 yang menyebutkan bahwa kemitraan merupakan kerjasama antara usaha kecil dengan memperlihatkan prinsip saling memerlukan, saling memperkuat dan saling menguntungkan. Artinya diperlukan suatu kerjasama yang sinergis antara peternak atau usaha kecil yang memiliki lahan dan tenaga kerja dengan perusahaan besar yang mempunyai modal dan tenaga ahli, dibawah pengawasan pemerintah dengan tujuan untuk menggali potensi peternakan.

Kemitraan merupakan suatu strategi dalam meningkatkan kinerja pelaku agribisnis khususnya peternak kecil. Pada pola kemitraan pihak perusahaaan memfasilitasi pengusaha kecil dengan modal usaha, teknologi, manajemen yang modern dan kepastian pemasaran hasil, sedangkan pengusaha kecil melakukan proses produksi sesuai dengan petunjuk teknis dari pihak pengusaha besar. Sinergi antara pihak yang memiliki modal kuat, teknologi maju, manajemen modern dengan pihak yang memiliki lahan, dan tenaga kerja dapat menghasilkan tingkat efisiensi dan produktivitas yang optimal. Tujuan kemitraan usaha agribisnis adalah untuk membantu para pelaku agribisnis (peternak dan pengusaha serta pihak-pihak terkait) dalam mengadakan kerjasama kemitraan yang saling menguntungkan dan bertanggung jawab.

Kemitraan diharapkan menjadi solusi untuk merangsang tumbuhnya agribinis peternakan terutama mengatasi masalah peternak yang kurang dalam hal permodalan, teknologi, pemasaran dan manajemen. Hal ini membutuhkan kerjasama dan kepercayaan antara perusahaan mitra dengan peternak ayam. Bergabungnya peternak dalam kemitraan ayam pedaging dilakukan untuk memenuhi harapan peternak yaitu peningkatan nilai tambah bagi usaha ternaknya,

Penelitian ini bertujuan untuk mengetahui persepsi peternak ayam pedaging (broiler) di Kecamatan Pondok Kubang Kabupaten Bengkulu Tengah. Persepsi peternak tentang kemitraan yang telah dilakukan antara peternak dan perusahaan inti dapat menjadi masukan yang penting bagi perusahaan ternak untuk dapat meningkatkan kerjasama dan keberhasilan peternak di masa depan.

\section{METODE PENELITIAN}

Penentuan lokasi penelitian dilakukan secara sengaja (purposive) yaitu berdasarkan kemudahan akses peneliti untuk mendapatkan data. Berdasarkan kriteria tersebut ditetapkan lokasi penelitian adalah di Kecamatan Pondok Kubang Kabupaten Bengkulu Tengah. Penelitian ini dilaksanakan mulai bulan Juni sampai Oktober 2019. 
Penelitian ini menggunakan metode survey dengan menjadikan peternak sebagai sumber data primer (data utama). Menurut sugiyono (2014) penelitian survey adalah penelitian yang dilakukan pada populasi besar maupun kecil, tetapi data yang dipelajari adalah data dari sampel yang diambil dari populasi tersebut, sehingga ditemukan kejadian-kejadian relative, distribusi, dan hubunganhubungan antar variabel sosiologis maupun psikologis. Responden adalah peternak (suami/isteri) ataupun anggota keluarga lainnya yang ikut bertanggung jawab dan ikut mengelola usaha peternakan. Jumlah responden adalah seluruh peternak yang melakukan kemitraan di Kecamatan Pondok Kubang yaitu sebanyak 4 orang peternak yang diambil berdasarkan jumlah seluruh peternak mitra PT. Ciomas Adisatwa yang ada di Kecamatan Pondok Kubang Kabupaten Bengkulu Tengah.

Data yang digunakan dalam penelitian ini adalah data primer yang berasal dari responden yang diwawancarai dan data sekunder yang berasal dari jurnal maupun kepustakaan lainnya. Pengumpulan data menggunakan teknik wawancara tidak terstruktur dengan tujuan data dan informasi yang diperoleh terkait persepsi peternak terhadap kemitraan yang mereka lakukan dapat diketahui.

Analisis data dalam penelitian ini dilakukan dalam tiga tahapan merujuk pada tahapan analisis data oleh Sugiyono (2014) yaitu yang pertama melakukan reduksi data sehingga data yang diperoleh dilapangan lebih fokus pada hal-hal yang penting, tahap kedua melakukan penyajian data dengan menggunakan tabel dan tahap yang ketiga dilakukan penarikan kesimpulan dari analisis yang dilakukan.

Analisa yang dilakukan untuk menjawab tujuan penelitian yaitu mengetahui persepsi peternak terhadap pola kemitraan yang dilaksanakan dengan PT. Ciomas Adisatwa Bengkulu digunakan teknik analisis deskriptif kualitatif dengan metode skoring data berkenaan dengan alternative jawaban penilaian peternak terhadap kemitraan yang telah dijalankan. Matrik tabel dibuat berdasarkan tanggapan peternak terhadap pertanyaan yang diajukan melalui kuisioner (daftar pertanyaan) dan wawancara. Rentang kategori skor jawaban responden dikategorikan atas 3 yaitu Tidak Baik skor (3-6), Cukup baik (7- 10) dan Tidak Baik (11 - 15). Untuk lebih jelasnya skor nilai jawaban terhadap penilaian persepsi peternak disajikan pada Tabel 1.

Tabel 1. Skor Penilaian Persepsi Peternak Mitra

\begin{tabular}{lcc}
\hline \multicolumn{1}{c}{ Kategori } & Skala & Skor \\
\hline Baik (B) & 1 & $11-15$ \\
Cukup Baik (CB) & 2 & $7-10$ \\
Tidak Baik (TB) & 3 & $3-6$ \\
\hline
\end{tabular}

222 | Rahmi Yuristia, Bambang Sumantri; Analisis Persepsi Peternak... 


\section{HASIL DAN PEMBAHASAN}

\section{Karakteristik Peternak Mitra}

Karakteristik responden dalam penelitian meliputi umur, tingkat pendidikan, pengalaman beternak dan jumlah ternak. Rata-rata umur reponden adalah 35 tahun. Umur peternak responden berada pada usia produktif, dimana menurut Mantra (2003) batas umur produktif di Indonesia adalah pada kelompok umur 15 sampai 64 tahun.

Berdasarkan tabel 2 dapat diketahui bahwa 50\%tingkat pendidikan responden adalah tamatan perguruan tinggi dan 50\% adalah tamatan Sekolah Menengah Atas (SMA) . Tinggi rendahnya tingkat pendidikan yang dimiliki oleh peternak sangat berpengaruh terhadap kemampuan mereka dalam menerima penyuluhan dan pengetahuan yang diberikan. Sehingga hal ini menunjukkan bahwa informasi berkenaan dengan usaha ternak ayam pedaging yang mereka dapatkan terkait dengan skala usaha yang mereka jalankan cukup baik.

\section{Tabel 2. Karakteristik Peternak Mitra}

\begin{tabular}{llc}
\hline No. & \multicolumn{1}{c}{ Karakteristik } & Persentase (\%) \\
\hline 1. & Umur Peternak (tahun): & \\
& $18-33$ & $25 \%$ \\
& $34-49$ & $75 \%$ \\
& $50-65$ & \\
2. & Tingkat Pendidikan: & \\
& SMA & $50 \%$ \\
& Perguruan Tinggi & $50 \%$ \\
3. & Pengalaman Beternak (Tahun): & \\
& $3-7$ & $25 \%$ \\
& $8-12$ & $50 \%$ \\
& $>12$ & $25 \%$ \\
4. Jumlah Ternak (ekor): & \\
& $5000-10000$ & $25 \%$ \\
& $10001-20000$ & $50 \%$ \\
& $>20000$ & $25 \%$ \\
\hline
\end{tabular}

Sumber : Data diolah 2019

Untuk pengalaman responden dalam berusaha ternak ayam pedaging diketahui bervariatif antara 5 sampai 12 tahun. Pengalaman dalam berusaha merupakan salah satu factor penentu dalam meningkatkan produktivitas kerja. Semakin lama korbanan waktu yang diberikan dalam suatu pekerjaan, maka akan semakin mahir seseorang dalam melakukan pekerjaan tersebut. Selai itu, lamanya pengalaman usaha ini tentunya akan menjadi penunjang dalam berusaha ternak ayam pedaging dan budidayanya. 
Untuk jumlah ternak yang dimiliki oleh responden berkisar antara 5000 sampai 20.000 ekor. Menurut Rahmat (2011), semakin besar skala usaha ternak ayam pedaging akan menghasilkan produktivitas usaha yang semakin besar pula. Hal ini tentunya berimbas pada keuntungan yang didapat oleh peternak.

\section{Persepsi Peternak Terhadap Kemitraan dengan Perusahaan Inti}

Menurut Rakhmat (2004), Persepsi adalah pengalaman seseorang tentang objek, peristiwa atau hubungan - hubungan yang diperoleh dengan menyimpulkan informasi dan menafsirkan pesan. Persepsi adalah pandangan atau sikap terhadap sesuatu hal yang menumbuhkan motivasi, dorongan,kekuatan dan tekanan yang menyebabkan seseorang melakukan sesuatu atau tidak melakukan sesuatu.

Dalam penelitian ini tanggapan yang diberikan adalah Kesesuaian pendapat dengan perusahaan inti, Manfaat sosial ekonomi dari kemitraan dan Keterbukaan informasi antara peternak mitra dengan perusahaan inti dalam kemitraan, dimana peternak di Kecamatan Pondok Kubang Kabupaten Bengkulu Tengah berposisi sebagai mitra/plasma sedangkan PT. Ciomas Adisatwa sebagai inti. Persepsi peternak terhadap kemitraan diketahui melalui pernyataan- pernyataan yang telah disampaikan melalui kuisioner yang telah di berikan kepada peternak responden.

\section{Persepsi Peternak Terhadap Kesesuaian Pendapat Dengan Perusahaan Inti}

Kemitraan usaha peternakan tertuang dalam UU No 18/2009 juncto UU No 41/2014 tentang Peternakan dan Kesehatan Hewan, Peraturan Pemerintah No 6/2013 tentang Pemberdayaan Peternak. Kemitraan Usaha Peternakan menitikberatkan pada kemitraan usaha peternakan berdasarkan perjanjian tertulis antarpelaku kemitraan yang diketahui oleh pemerintah. Pengembangan ayam pedaging melalui pola kemitraan terdapat suatu kerjasama yang berkaitan dengan kontrak perjanjian yang isinya perusahaan inti dalam penyediaan sapronak, penentuan harga, jaminan dan resiko telah disepakati antara dua belah pihak.

Pelaksanaan kemitraan yang dijalankan oleh PT. Ciomas Adisatwa merupakan kerjasama mitra plasma-inti. Pola kemitraan inti plasma merupakan hubungan antara petani, kelompok tani, atau kelompok mitra sebagai plasma dengan perusahaan inti yang bermitra usaha. Sementara mitra bertugas memenuhi kebutuhan perusahaan inti sesuai dengan persyaratan yang telah disepakati.

224 | Rahmi Yuristia, Bambang Sumantri; Analisis Persepsi Peternak... 
Tabel 3. Kesesuaian Pendapat Dengan Perusahaan Inti

\begin{tabular}{cccc}
\hline $\begin{array}{c}\text { Persepsi Peternak } \\
\text { (Kategori) }\end{array}$ & Persentase & $\begin{array}{c}\text { Rata-rata } \\
\text { (Skor) }\end{array}$ & $\begin{array}{c}\text { Kisaran Skor } \\
\text { (Min-Max) }\end{array}$ \\
\hline Baik (B) & $25 \%$ & & $11-15$ \\
Cukup Baik (CB) & $75 \%$ & 9,75 & $7-10$ \\
Tidak Baik (TB) & $0 \%$ & & $3-6$ \\
\hline
\end{tabular}

Sumber : Data diolah 2019

Persepsi peternak terhadap kesesuaian pendapat dengan perusahaan inti dapat dilihat pada tabel 3.Berdasarkan hasil analisa persepsi yang dilakukan terhadap peternak didapatkan skor rata-rata persepsi peternak terhadap kesesuian pendapat dengan perusahaan inti secara keseluruhan adalah 9,75 yang artinya persepsi peternak berada pada rentang kategori cukup baik (CB) dimana kategori Cukup baik berada pada kisaran skor 7 - 10. Adapun persentase dari persepsi peternak responden didapatkan bahwa 75\% dari responden memiliki persepsi Cukup Baik, 25\% dari responden memiliki persepsi Baik dan 0\% atau tidak ada dari peternak yang memiliki pesepsi tidak baik terhadap kesesuaian pendapat dengan perusahaan inti.

\section{Persepsi Peternak Terhadap Manfaat Sosial Ekonomi Dari Kemitraan}

Berdasarkan tabel 4 tergambar bahwa persepsi yang diberikan peternak terhadap kemitraan yang terjalin antara peternak mitra dan perusahaan inti memiliki manfaat sosial ekonomi yang di kategorikan Cukup Baik (CB). Dikategorikan Cukup Baik karena memiliki skor rata-rata 10,50 yang artinya persepsi peternak berada pada kisaran skor 6 - 10. Hal ini terlihat dari jawaban responden dimana 75\% menjawab Cukup Baik dan 25\% menjawab Baik. Kemitraan ayam broiler memberikan dampak yang baik bagi peternak mitra karena mereka mampu menjangkau manajemen usaha yang kuat yang mampu mengatasi permasalahan bisnis. Berbeda dengan peternakan rakyat yang tidak melakukan kemitraan dengan perusahaan inti.

\section{Tabel 4. Manfaat Sosial Ekonomi Dari Kemitraan}

\begin{tabular}{lccc}
\hline $\begin{array}{c}\text { Persepsi Peternak } \\
\text { (Kategori) }\end{array}$ & Persentase & $\begin{array}{c}\text { Rata-rata } \\
\text { (Skor) }\end{array}$ & $\begin{array}{c}\text { Kisaran Skor } \\
\text { (Min-Max) }\end{array}$ \\
\hline Baik & $25 \%$ & & $11-15$ \\
Cukup Baik & $75 \%$ & 10,50 & $6-10$ \\
Tidak Baik & $0 \%$ & & $3-6$ \\
\hline
\end{tabular}

Sumber : Data primer diolah 2019

Atribut yang digunakan dalam melihat persepsi peternak terhadap manfaat social ekonomi dari kemitraan adalah bagaimana lapangan kerja tercipta dari adanya kerjasana kemitraan usaha peternakan, meningkatnya 
kemampuan peternak dalam pengetahuan budidaya ayam pedaging, resiko kerugian usaha yang relative kecil, harga penjualan hasil peternakan atau ayam stabil sesuai dengan kontrak yang telah disepakati, serta bagaiman peternak mendapatkan jaminan pemasaran.

Walaupun respon persepsi peternak cukup baik dalam manfaat social ekonomi dari kemitraan, namun diketahui dari lapangan bahwa peternak mitra cenderung hanya sebagai pelaku budidaya saja sehingga untuk permasalahan pasar dan konsumen peternak tidak ikut campur tangan. Peternak hanya bertindak sebagai penerima harga. Harga kandang memiliki margin yang besar disbanding harga pasar. Sehingga ketika harga pasar naik, peternak tidak mendapatkan efek yang begitu besar.

\section{Persepsi Peternak Terhadap Keterbukaan Informasi Antara Peternak Mitra Dengan Perusahaan Inti Dalam Kemitraan}

Kemitraan memiliki prinsip-prinsip dalam pelaksanaannya. Salah satunya adalah Transparansi. Transparansi diperlukan untuk menghindari rasa saling curiga antar mitra kerja. Meliputi transparansi pengelolaan informasi antara peternak mitra dengan perusahaan inti. Selain itu menjalin kerjasama mitra tentunya didasarkan prinsip saling menguntungkan antara peternak dan perusahaan. Persayaratan mengikuti pola kemitraan merupakan dasar dari kerjasama yang dilakukan. Persyaratan utamanya adalah jujur dan dapat dipercaya tanpa adanya seleksi terlebih dahulu.

Untuk melihat persepsi peternak terhadap keterbukaan informasi antara peternak mitra dengan perusahaan inti dapat dilihat pada tabel 5 . Persepsi peternak dalam kemitraan yang terjalin termasuk dalam kategori Baik dengan hasil skor rata-rata yang didapat adalah 12,25 . Seluruh peternak $(100 \%)$ memiliki persepsi yang sama dengan. Hal tersebut mengindikasikan bahwapeternak mitra berpendapat sudah ada kesesuaian dan transparansi informasi antara harapan peternak dengan informasi yang diberikan oleh perusahaan inti.

\section{Tabel 5. Keterbukaan Informasi Antara Peternak Mitra Dengan Perusahaan}

Inti Dalam Kemitraan

\begin{tabular}{lccc}
\hline $\begin{array}{c}\text { Persepsi Peternak } \\
\text { (Kategori) }\end{array}$ & Persentase & $\begin{array}{c}\text { Rata-rata } \\
\text { (Skor) }\end{array}$ & $\begin{array}{c}\text { Kisaran Skor } \\
\text { (Min-Max) }\end{array}$ \\
\hline Baik & $100 \%$ & 12,25 & $11-15$ \\
Cukup Baik & $0 \%$ & & $7-10$ \\
Tidak Baik & $0 \%$ & & $3-6$ \\
\hline
\end{tabular}

Sumber : Data diolah 2019

226 | Rahmi Yuristia, Bambang Sumantri; Analisis Persepsi Peternak... 
Sebagai cerminan dari terjalinnya kemitraan yang baik antara peternak dengan perusahaan adalah selama ini tidak ada terjadi konflik antara peternak dan perusahaan. Namun yang paling mendasar yakni telah dijalankannnya prinsip-prinsip kemitraan secara baik oleh pihak-pihak yang bermitra. Hal ini sejalan dengan penelitian Zaelani (2008), bahwa kepercayaan sangat mempengaruhi kemitraan. Dengan demikian apabila banyak mitra yang terlibat dalam suatu usaha dan terikat dalam suatu kepercayaan maka usaha peternakan akan berdampak baik kepada peternak dan mitra dalam suatu kemitraan.

\section{SIMPULAN DAN SARAN}

\section{Simpulan}

Berdasarkan penelitian yang telah dilakukan Terhadap Peternak mitra di Kecamatan Pondok Kubang Kabupaten Bengkulu Tengah maka didapat simpulan bahwa persepsi peternak terhadap kemitraan yang telah terjalin tergolong baik, hal ini terlihat dari skor perolehan yang didapat yaitu persepsi peternak tentang kesesuaian pendapat dengan perusahaan inti adalah $75 \%$ peternak menjawab Cukup Baik dengan Skor Rata-rata 9,75; persepsi peternak di terhadap manfaat social ekonomi dari kemitraan yang telah berlangsung adalah 75\% peternak menjawab Cukup Baik dengan Skor Rata-rata 10,50; dan persepsi peternak terhadap keterbukaan informasi antara peternak mitra dengan perusahaan inti dalam kemitraan adalah $100 \%$ peternak menjawab Baik dengan skor rata-rata 12,25 .

\section{Saran}

Untuk menjaga persepsi peternak selalu baik dan terjaga kerjasama yang menguntungkan maka pihak perusahaan inti di sarankan agar dapat selalu berkoordinasi dengan peternak sehingga tidak ada perbedaan pendapat yang dapat menghalangi kerjasama ke depannya. Selain itu agar peternak dan perusahaan selalu melakukan evaluasi terhadap kontrak yang telah dilakukan demi peningkatan hasil kerjasama kemitraan.

\section{DAFTAR PUSTAKA}

Hafsah, M. J. 1999. Kemitraan Usaha Konsepsi dan Strategi. Jakarta. Departemen Pertanian.

Mantra, Ida Bagus Dr. 2003.Demografi Umum. Edisi kedua. Yogyakarta. Pustaka Pelajar.

Maslow, A.H. 1994. Motivasi dan Kepribadian I. (Terjemahan : Nurul Iman). Yogyakarta. LPPM dan PT. Pustaka Binaman Pressindo. 
Notoatmodjo, S. 2003. Ilmu Kesehatan Masyarakat (prinsip - prinsip dasar). Jakarta. Rineka Cipta.

Rahmat, R. 2003. Ayam Buras Intensifikasi dan Kiat Pengembangan. Yogyakarta. Kanisius.

Rakhmat, Jalaluddin, 2004. Psikologi Komunikasi. Bandung. PT . Remaja Rosdakarya.

Rasyaf, Muhammad. 2001. Beternak Ayam Petelur. Jakarta. Penebar Swadaya.

--.-. 2001. Manajemen Peternakan Ayam Petelur. Jakarta. Penebar Swadaya.

Soekartawi. 1999. Agribisnis (Teori \& Aplikasinya). Jakarta. PT RajaGrafindo Persada.

Sugiyono. (2014). Metode Penelitian Pendidikan Pendekatan Kuantitatif, Kualitatif, dan RED. Bandung: Alfabeta.

Zaelani, Achmad. 2008. Manfaat Kemitraan Agribisnis Bagi Petani Mitra (Kasus: Kemitraan PT Pupuk Kujang Dengan Kelompok Tani Sri Mandiri DesaMajalaya Kecamatan Majalaya Kabupaten Karawang, Provinsi Jawa Barat). (skripsi). Institut Pertanian Bogor. Bogor.

Zeithaml, V. and Bitner, M.J. 2003. Services Marketing. 3Rd Ed. McGraw-Hill Irwin, Boston, United Stated of Amerika.

228 | Rahmi Yuristia, Bambang Sumantri; Analisis Persepsi Peternak... 